\title{
Building GIS Application Model in Support of Tsunami Relief Effort
}

\author{
Asha Nilani Liyanage ${ }^{1}$, Heewon Lee ${ }^{1^{*}}$ and Seok-Hwan Lee ${ }^{2}$ \\ ${ }^{1}$ Division of Architecture, Sun Moon University \\ ${ }^{2}$ Department of Urban Design \& Development, Kyungsung University \\ 쓰나미 재난 대응을 위한 GIS 응용모델 구축에 관한 연구 \\ 아샤 리야나게 ${ }^{1}$, 이희원 $1^{*}$, 이석환 $^{2}$ \\ ${ }^{1}$ 선문대학교 건축학부, ${ }^{2}$ 경성대학교 도시공학과
}

\begin{abstract}
Tsunami happens rarely enough to allow a false sense of security, but when they do occur, there may be just minutes or hours for people to reach a safe location. Natural disasters like tsunami are inevitable and it is almost impossible to fully recoup damages caused by the disasters. However, it is possible to minimize the potential risk by developing early warning strategies. GIS modelling with its geoprocessing and analysis capability can play a crucial role in efficient mitigation and management of disaster. This study aims at developing integrated spatial information system processing model supporting tsunami evacuation action planning using geo-information technology such as GIS. The integration process classified into four phases. And in each phase, required input data and GIS processes are decided. The main effort in minimizing casualties in tsunami disaster is to evacuate people from the hazard area before tsunami strikes by means of either horizontal or vertical evacuation. The study provides essential spatial information for local decision making related with people's evacuation in tsunami-prone areas based on a modeling approach transferable to other coastal areas.
\end{abstract}

요 약 쓰나미라 불리는 지진해일은 드물게 일어나는 현상이지만 일어날 경우 대피할 수 있는 시간이 촉박하며, 엄 청남 인명, 재산피해를 유발하므로 이에 대한 대비는 매우 중요하다. 쓰나미는 자연재해로 그 피해를 원상 복구하는 것은 거의 불가능하나 조기경보체계 등을 통하여 대피함으로서 인명피해를 최소화 할 수 있다. 이러한 자연재해에 대 한 피해경감과 재난관리를 위하여 GIS의 지오프로세싱 기능과 분석기능은 유용한 도구가 될 수 있다. 본 연구는 쓰 나미의 경우에 있어서 GIS의 지리정보 프로세싱 기능을 이용하여 대피계획 수립에 필요한 관련정보 통합 프로세싱 모형을 구축하고자 하는데 그 목적이 있다. 쓰나미의 경우 주된 대피는 인구를 발생지역으로부터 수평적, 또는 수직 적으로 이동시키는 것과 관련이 있으며, 이를 위한 대피와 대응의 과정을 4단계로 구분 하였으며, 각 단계마다 필요 한 입력데이터를 정하였다. 최종모형은 이러한 4단계를 통합하여 최종모형으로 제시하였다. 본 연구에서 설정된 모델 은 매 단계의 입력데이터를 달리하여 쓰나미 발생이 예상되는 해안도시에 적용할 경우 인구의 대피와 관련한 의사결 정에 활용될 수 있다.

Key Words : Tsunami evacuation, GIS, Process modelling

\section{Introduction}

\subsection{Background}

On December 26, 2004, with an epicenter off the west coast of Sumatra, Indonesia, the Sumatra-Andaman earthquake resulted in tsunami, a huge wall of water waves. With a magnitude of between 9.1 and 9.3, it is the third largest earthquake ever recorded on a seismograph

*Corresponding Author: Heewon Lee(Sun Moon Univ.)

Tel: +82-41-530-2327 email: heewon@sunmoon.ac.kr

Received December 13, 2012 Revised February 15, 2013

Accepted March 7, 2013 
caused by seduction and triggered a series of devastating tsunami along the coasts of most landmasses bordering the Indian Ocean, killing over 230,000 people in fourteen countries, and inundating coastal communities with waves up to 30 meters (100 feet) high. It was one of the deadliest natural disasters in recorded history. Indonesia was the hardest hit, followed by Sri Lanka, India, and Thailand[1].

Tsunami mean "harbor wave" in Japanese term. Underwater earthquakes, landslides, or other major deformations that cause large vertical displacements of water generate tsunami[2].

Tsunami is most common in the Pacific Ocean, with small, nearly undetectable tsunami occurring regularly. Although wave height is relatively small in open seas, when the tsunami hits the coastline, it may rise to several meters and can cause loss of lives and property damage when comes to shores. Major tsunami events are extremely rare, though the Indian Ocean tsunami of December 2004 showed that major tsunami events can have devastating effects over very large area[3].

Though human cannot prevent tsunami, as it is a natural occurrence, we can minimize the damage.

\subsection{Objectives and Methodology}

This paper discusses the areas which we can apply GIS applications to minimize the damages occurred by tsunami, and will propose a model which we can utilize with GIS model builder application (the interface used to build and edit geoprocessing models in ArcGIS program/ http://wiki.gis.com/wiki/index.php/GIS_Glossary/M) to make 'run-up plans (the maps and methods that used for evacuation in case of emergency). By this system, people can integrate tsunami analysis tools into a GIS workplace. Further, this provides concepts to identify the implementation of technology and the data implementing ideas for calculations that needed in an emergency situation.

To fulfill above mentioned objectives, this study mainly focused on how to make 'run-up' plans, widely means as an evacuation plans. This focuses mainly with the flow or the model builder function of GIS. It will discuss about the phases and flows for building up the 'run-up' models in ArcGIS process, and this geoprocessing (A GIS operation used to manipulate GIS data. A typical geoprocessing operation takes an input dataset, performs an operation on that dataset, and returns the result of the operation as an output dataset. Common geoprocessing operations include geographic feature overlay, feature selection and analysis, topology processing, raster processing, and data conversion. Geoprocessing allows for definition, management, and analysis of information used to form decisions/ http://wiki.gis.com/wiki/index.php /GIS_Glossary/G) -based model can be used to automate, run, and re-run a ArcGIS process. This model is especially useful for complex data processing flows that need to be executed rapidly during and disaster situation.

\section{GIS Possibilities for Tsunami Disaster Management}

Since tsunami is natural disaster it is impossible to forecast the exact date and time of its occurrence to fully prepare people evacuation. But, we can prepare and manage this situation with use of technologies like GIS. (geographic information system) The tsunami disaster management can be classified into two part: pre-disaster management and post-disaster management.

GIS technology can be effectively used to both preand post-disaster planning. Planning for pre-disaster management involves predicting the area and time of a possible disaster and the impacts on human life, property, and environment. Pre-disaster management concerns with the measures to prevent negative impacts from hazard events and to be better prepared for those that are not prevented whereas post-disaster relief and recovery measures. Pre-disaster management is risk management that has three components: risk identification, risk reduction, and risk transfer and preparedness, the post-disaster phase is devoted to emergency response, rehabilitation and reconstruction[4].

GIS allows quickly accessing and visually displaying critical information by location that helps in developing action plans[5]. Emergency disaster management requires response, incident mapping, establishing priorities, developing action plans, and implementing the plan to protect lives, property, and the environment. Effective disaster management requires assimilation and dissemination of preplanned, historical and real-time information to many 
sources. To deal with this issue, not only basic activities but also technological solutions should be used. In this sense, information about human populations, infrastructure and other spatially distributed data can be managed by the use of GIS technologies.

\section{Building GIS Model: Phases and Flows for 'Run-Up' Plans}

Modeling processes are divided into four main phases, which is interrelated to one phase to another. Since GIS model builder contains mainly three flows, namely input, process and output, following four phases will be described according to those three flows.

Modeling for Mapping and Analysis Task Lists:

-Phase One: Build up evacuation zone map.

-Phase Two: Build up emergency evacuation routes map.

-Phase Three: Build up emergency resources location map.

-Phase Four: Build up at-risk population map.

\subsection{Phase One (Build Up Evacuation Zone Map)}

Purpose of the first phase is mainly defining the warning areas in post disaster time. It shows the areas which can be damaged due to tsunami.

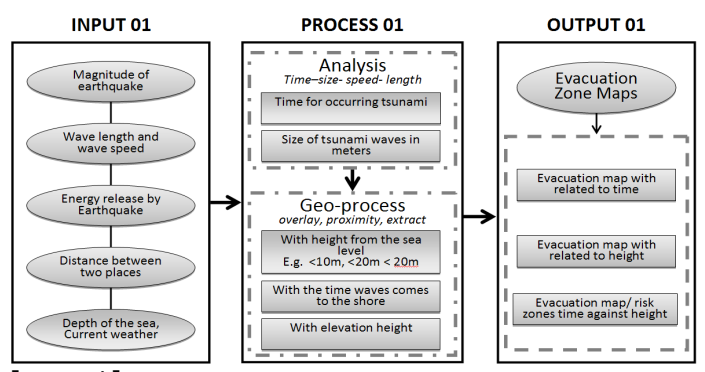

[Fig. 1] Phase 1 model of Evacuation Zone Map

\subsubsection{Input data}

As the first phase of the modeling, size of tsunami should be input to the system. This is done after the earthquake happened. The size of tsunami depends with the several factors as follows; The magnitude of the earthquake / Energy released by earthquake / Distance between earthquake happen place and causing area/ Other factors (Depth of the sea earthquake happen, current weather conditions, etc.)

\subsubsection{Process}

Classify the evacuation zone areas according to the height from the sea level; (00-10m) Elevation height / (10-20m) Elevation height / (20-30) Elevation height. This leads to make results of phase one according to the size of tsunami waves and its height given by input of phase one.

\subsubsection{Output}

The zoning of risk zone map is the output of phase one. These zones will be used to prioritize evacuation efforts and allocate guard and rescue personnel and emergency resources and supplies.

\subsection{Phase Two (Build Up Emergency Evacuation Routes Map)}

Transportation facilities can itself suffer from both artificial and natural disaster. Transportation system can play crucial role in disaster response if it monitored well and assessed properly. An effective transportation system provides much help to take and the affected peoples to safer places and rescue and relief material to the disaster hit areas within very short time. Therefore, as th second phase model build emergency evacuation route map mainly for; Evacuation the population in the area of the event / Provide emergency access to the site of the incident / Allow the public to bypass the affected area / Respond to the impacts of restrictions to access in the affected area.

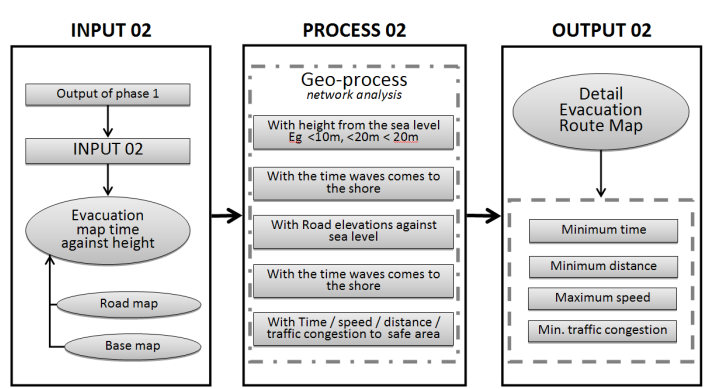

[Fig. 2] Phase 2 model of Evacuation Routes Map 


\subsubsection{Input data}

The output of phase one will be the main input for phase two. Further it will basically overlap with base map of the area and detailed routes maps.

\subsubsection{Process}

With the results that found in phase one and the road maps, the process should be gone through the processing of; Achieving minimum traffic congestions / Showing more than one optional route and several usages of routes for different areas while it should consume minimum time, allocating maximum speed.

\subsubsection{Output}

Shows the emergency routes map to reach safer zones. This map is massively helpful for the peoples who are in the dangerous areas, and also people who are going to aid for the risk areas.

\subsection{Phase Three (Build Up Emergency Resources Location Map)}

With optimal utilization for relief and evacuation purposes, a reliable map portraying the location of the emergency resources like water, service units, food warehouses, transport and communication networks and other utilities is very crucial in disaster management with acquisition of real-time(RT) information about the status of the resources.

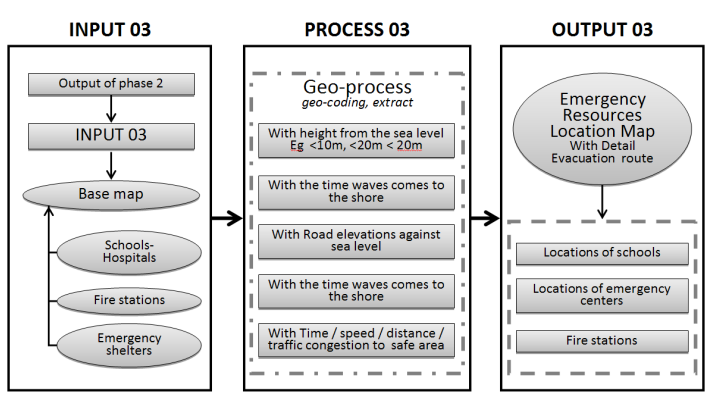

[Fig. 3] Phase 3 model of Emergency Resources Location Map

\subsubsection{Input data}

The result of phase two will be the main input for phase three. Further it will overlap with base map of the area, resource location maps.

\subsubsection{Process}

This will process important location such as schools, hospital, fire station, emergency shelters, etc. and resources with the emergency route map.

\subsubsection{Output}

Resource location map is the output of this phase, a map which can highly be used in an emergency situation.

\subsection{Phase Two (Build Up At-Risk Population Map)}

The main purpose of this is to determine the at-risk population in an emergency situation. Identifying most risky areas and high population dense areas, this can be used mostly by those as aid organization to reach those sites by vertical transport devices.

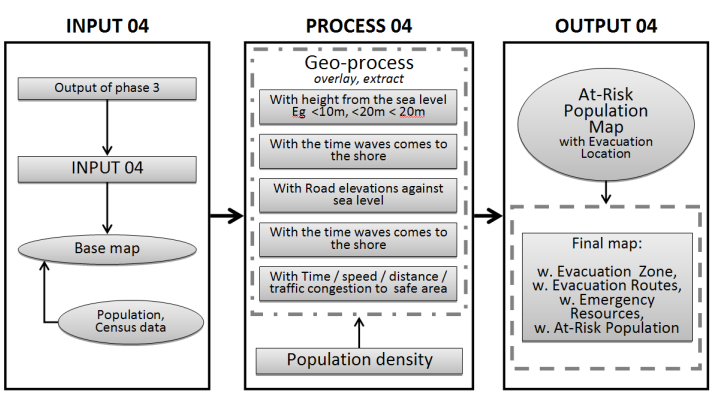

[Fig. 4] Phase 4 model of At-Risk Population Map

\subsubsection{Input data}

With the output of phase three, it will overlap with the population map.

\subsubsection{Process}

Estimate the at-risk population within each zone as well as the base map calculated and process the at-risk population map.

\subsubsection{Output}

As the output of the final phase can determine the at-risk population, emergency evacuation helping can be patched according to the results shown at-risk population map. 


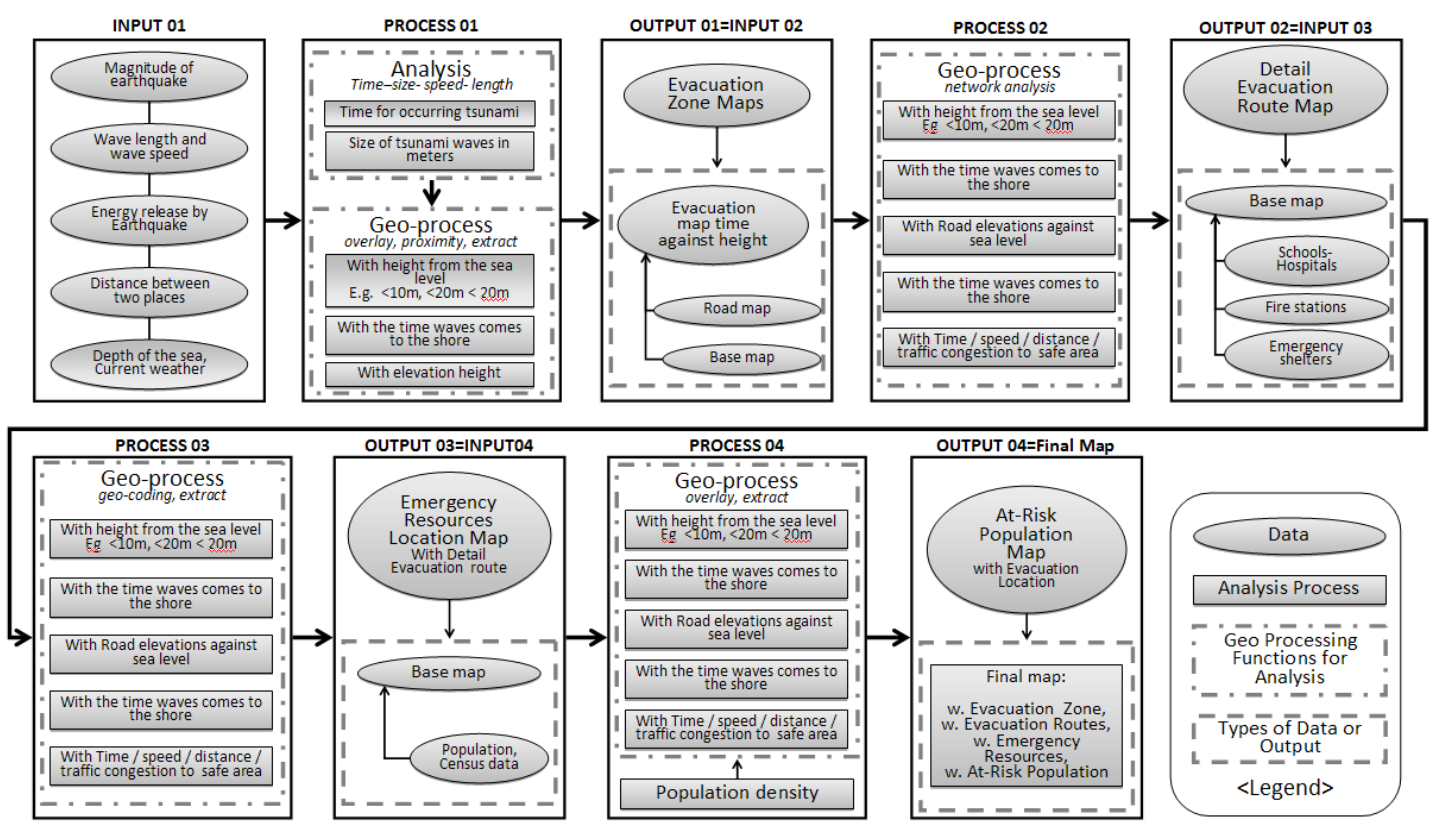

[Fig. 5] Combined Model for Tsunami Relief GIS Application

\section{Conclusion}

By overlapping four phases, the final detailed evacuation map can be made. The following final combined model shows the connection between the all four phases and their results.

The main outcomes of the study elaborate several uses of GIS that can help to evacuate from risk, in determining the inundated buildings and roads and calculating the optimum routes to the closest facilities in case of tsunami emergency, based on the source data gathered.

It is also vital that human should have learnt from the experience of previous disasters, by capturing and archiving the GIS methods that worked, by documenting lessons learned, and by iterating designs and plans.

This study will help to improve preparation of the evacuation plan which can be organized by the government in case of a tsunami disaster. Inundation map generated for the study by the result of a tsunami simulation is a guide for areas to be protected and evacuation map and network analysis conducted for the case of emergency is a guide map for the hot points which should be evaluated for the rescue operation at the first place.
Catastrophic events like tsunami, earthquakes, and floods cannot be eliminated, however, precautions system always should be developed. Especially by the help of developing technologies, the preparedness to those kinds of events can be possible. By using GIS in this sense, the risk maps and evacuation plans can be arranged for disaster management and those outputs can be used in the emergency action plans, for making emergency decisions and future decisions for new city planning implementations.

\section{References}

[1] 2004 Indian Ocean earthquake and tsunami, http://en.wikipedia.org/wiki/2004 Indian Ocean earthqu ake and tsunami (accessed Aug., 2012)

[2] Tsunami Geology - What Causes a Tsunami?, http://geology.com/articles/tsunami-geology.shtm (accessed Oct., 2012)

[3] Tsunami Facts and Information,

http://www.bom.gov.au/tsunami/info (accessed Sep., 2012)

[4] Paul K. Freeman, Leslie A. Martin, Joanne Linnerooth-Bayer, Reinhard Mechler, Georg Pflug, Koko Warner, "Disaster Risk Management: National Systems for the Comprehensive management of Disaster 
Risk and Financial Strategies for Natural Disaster Reconstruction", Inter-American Development Bank, Washington, D.C., 2003

[5]. Seda Şalap, Aykut Ayça, Zuhal Akyürek, Ahmet Cevdet Yalçıner, "Tsunami Risk Analysis and Disaster Management by Using GIS: A Case Study in Southwest Turkey", Göcek Bay Area. Middle East Technical University (METU), Turkey, 2001

\section{Asha Nilani Liyanage}

[Regular member]

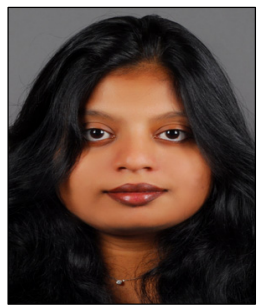

- 2009 : B. Arch(Hons) First Class (RIBA part1 \& 2)

- $2009 \sim 2010$ : Senior Architect, Hairu Engineering and Consultancy (PVT) Ltd., Kandy, Sri Lanka

- $2011 \sim$ current : Sun Moon Univ., Dept. of Architecture, Graduate School

$<$ Research Interests $>$

Sustainable Architecture, Biomimetic Architecture

\section{Heewon Lee}

[Regular member]

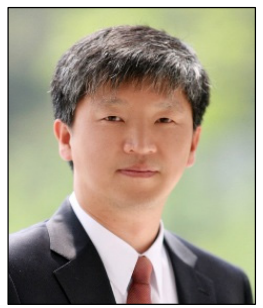

- Feb. 1989 : Seoul National Univ., Dept. of Architecture, MS

- Feb. 2003 : Seoul National Univ., Dept. of Architecture, Ph. D

- Mar. $1999 \sim$ current : Sun Moon Univ., Dept. of Architecture, Professor

$<$ Research Interests $>$

Architectural Design, Urban and Architectural GIS
Seok-Hwan Lee

[Regular member]

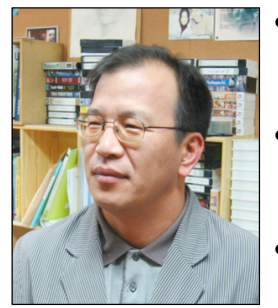

- Feb. 1991 : Seoul National Univ., Graduate School of Environmental Studies, MLA

- Feb. 1991 : Seoul National Univ., Graduate School of Environmental Studies, Ph. D

- Mar. $1999 \sim$ Current : Kyungsung Univ., Dept. of Urban Design \& Development, Professor

$<$ Research Interests $>$

Urban Planning \& Design, Landscape, Regeneration 